\title{
Recent Experience with Intermediate Scrutiny Under the North Carolina Constitution: Blankenship v. Bartlett and King ex rel. Harvey- Barrow v. Beaufort County Board of Education
}

\author{
Mark D. Martin \& Daniel F.E. Smith ${ }^{*}$
}

\section{INTRODUCTION}

In two recent interpretations of the North Carolina Constitution, the Supreme Court of North Carolina adopted and developed a unique form of intermediate scrutiny. Blankenship v. Bartlett ${ }^{1}$ addressed a challenge to judicial districts under the state equal protection clause. ${ }^{2}$ King ex rel. Harvey-Barrow v. Beaufort County Board of Education ${ }^{3}$ decided a state constitutional claim to alternative-education services during a disciplinary suspension. ${ }^{4}$ By applying intermediate scrutiny, the court resolved these two challenging state constitutional cases.

As the name implies - and as the bench and bar know very wellintermediate scrutiny falls somewhere "in between" strict scrutiny and rational basis review. ${ }^{5}$ Strict scrutiny, the "most exacting scrutiny," is applied to suspect classifications and those impinging on fundamental

* Senior Associate Justice and Research Assistant, Supreme Court of North Carolina. Nothing in this Article should be viewed as an opinion about the merits of pending or future cases that may come before the Supreme Court of North Carolina. The purpose of this Article is to chronicle significant legal developments in North Carolina and place them in the academic literature on state constitutional adjudication. The legal value vel non of these developments and their implications for future cases are left to the academy and other legal commentators. We wish to thank Justice Robert H. Edmunds, Tom Davis, and Jake Parker for their assistance with this Article.

1. 681 S.E.2d 759 (N.C. 2009).

2. See infra Part III.B.

3. 704 S.E.2d 259 (N.C. 2010).

4. See infra Part III.C.

5. See, e.g., William W. Burke-White \& Andreas von Staden, Private Litigation in a Public Law Sphere: The Standard of Review in Investor-State Arbitrations, 35 YALE J. INT’L L. 283, 317 (2010) ("In Equal Protection Clause jurisprudence, for example, a U.S. court selects a particular standard of review based on the nature of the divisions the legislation in question draws between classes of individuals. The more suspect the classification in question, the stricter the scrutiny employed by the tribunal. Legislation of a general nature is subject only to rational basis review; more suspect classifications, such as gender, are subject to intermediate scrutiny; the most suspect classes, such as race, are subject to strict scrutiny.”). 
rights $^{6}$ and requires that the classification be necessary to achieve a compelling governmental interest. ${ }^{7}$ Challenges that do not involve fundamental rights or suspect classes receive rational basis review, the minimum level of scrutiny, which requires a challenged classification to be "rationally related to a legitimate governmental purpose."” Intermediate scrutiny, which has generally been applied to classifications based on gender and illegitimacy, requires a classification to be "substantially related to an important government objective."

Through a review of Blankenship and King, this Article examines the origins of the particular form of intermediate scrutiny adopted by the Supreme Court of North Carolina. The North Carolina Constitution is a much more detailed document than the U.S. Constitution and thus potentially raises more issues for judicial resolution. In the words of a well-known scholar on the North Carolina Constitution, "[b]oth the grand declarations and the mundane details of a provision raise tricky problems of interpretation and implementation." ${ }^{\prime 10}$ Blankenship and King adopted intermediate scrutiny to resolve the "tricky problems" presented by those cases.

This Article proceeds by first providing background on the North Carolina Constitution and its interpretation by the Supreme Court of North Carolina. This background section places North Carolina constitutional adjudication in the context of nationwide trends and models of state constitutional adjudication. The Article then briefly reviews the application of intermediate scrutiny by federal and state courts before turning to Blankenship and King. After examining the application of intermediate scrutiny in those two cases, potential benefits and drawbacks of intermediate scrutiny are catalogued. This Article

6. Clark v. Jeter, 486 U.S. 456, 461 (1988) ("Classifications based on race or national origin and classifications affecting fundamental rights are given the most exacting scrutiny.” (citations omitted)).

7. Dep't of Transp. v. Rowe, 549 S.E.2d 203, 207 (N.C. 2001) ("If a regulation receives strict scrutiny, then the state must prove that the classification is necessary to advance a compelling government interest; otherwise, the statute is invalid.").

8. Clark, 486 U.S. at 461; see also Rowe, 549 S.E.2d at 207 ("If a regulation draws any other classification, it receives only rational-basis scrutiny, and the party challenging the regulation must show that it bears no rational relationship to any legitimate government interest. If the party cannot so prove, the regulation is valid.").

9. Clark, 486 U.S. at 461; see also Rowe, 549 S.E.2d at 207 ("Other classifications, including gender and illegitimacy, trigger intermediate scrutiny, which requires the state to prove that the regulation is substantially related to an important government interest.”).

10. John V. Orth, The North Carolina State Constitution, With History and COMMENTARY, at Xvi (1995). 
concludes that intermediate scrutiny may represent a viable alternative in resolving state constitutional dilemmas.

\section{THE NORTH CAROLINA CONSTITUTION AND ITS INTERPRETATION BY THE COURTS}

\section{A. A Brief History}

The State of North Carolina has had three constitutions. The "Independence Constitution" of 1776 and its accompanying Declaration of Rights enshrined the principle of separation of powers, expressly declared the right of citizens to be free from governmental interference, and elaborated the basic structure of government. ${ }^{11}$ It placed most of the power in the hands of the state legislature and the property owners who were the only citizens entitled to vote. ${ }^{12}$ Extensive amendments in 1835 reflected a westward shift in the political center of the state that resulted from frontier settlement. ${ }^{13}$

The "Reconstruction Constitution" of 1868 was drafted following the Civil War according to the requirements of federal legislation. ${ }^{14}$ It included the 1776 constitution's Declaration of Rights, strengthened the executive branch, expanded the right to vote, established a uniform court system, and elaborated the methods for taxation. ${ }^{15}$ Notably, a set of thirty amendments ratified in 1876 restored power to the state legislature that had been lost in the 1868 constitution. ${ }^{16}$

The current constitution was adopted in 1970 and took effect in 1971. ${ }^{17}$ It incorporated revisions recommended by a constitutional study commission chaired by a former chief justice of the Supreme Court of North Carolina. ${ }^{18}$ The commission's suggested revisions deleted obsolete or invalid provisions and consolidated and revised the constitutional text for clarity. ${ }^{19}$ "The 1971 Constitution ... was not ... a product of haste and social turmoil. It was instead a good-government

11. Id. at 1, 3-4; John L. Sanders, Our Constitutions: An Historical Perspective, in NORTH CAROLINA MANUAL: 1995-1996, at 136, 136 (Lisa A. Marcus ed., 1996).

12. See ORTH, supra note 10 , at 1 ; Sanders, supra note 11 , at 136.

13. See ORTH, supra note 10 , at 1 .

14. See id. at $12-13$.

15. Id. at 13-14; Sanders, supra note 11, at 138.

16. ORTH, supra note 10 , at 16 .

17. Sanders, supra note 11 , at 144

18. Id. at 143.

19. See ORTH, supra note 10, at 20; Sanders, supra note 11, at 143-44. 
measure, long matured and carefully crafted by the state's lawyers and politicians, designed to consolidate and conserve the best features of the past, not to break with it.,20

In general, amending state constitutions is easier than amending the U.S. Constitution, as plainly demonstrated by the numbers of amendments adopted. ${ }^{21}$ According to an estimate made in 1989, "[t]he present constitutions of the 50 states have been amended collectively in excess of 5300 times." $^{22}$ Averaged across the states, this represents 106 amendments for each state. ${ }^{23}$ A slightly later study from 1998 estimates that "state constitutions on average contain over 120 constitutional amendments.", 24

Like other states, North Carolina's constitution has been amended much more frequently than the U.S. Constitution. For example, in the period between 1869 and 1968, there were ninety-seven proposed amendments to the 1868 constitution; of these, voters ratified sixty-nine and rejected the other twenty-eight. ${ }^{25}$ The frequency of amendments to the North Carolina Constitution has continued to the present day. In the November 2010 elections, North Carolina voters approved an amendment that prevents convicted felons from running for the office of sheriff. $^{26}$ In an indication of how quickly an amendment to the state constitution can pass, the state legislature had submitted the amendment in a session law passed on July $1,2010,{ }^{27}$ just four months before the election. The next most recent amendments were presented during the 2004 elections - all three amendments passed and, respectively, addressed the distribution of civil fines and forfeitures to public schools, expanded the terms of magistrate judges, and authorized self-financing bonds for public improvements. ${ }^{28}$

20. ORTH, supra note 10, at 20.

21. See James R. Acker \& Elizabeth R. Walsh, Challenging the Death Penalty Under State Constitutions, 42 VAND. L. REV. 1299, 1329 (1989) ("State constitutions also are more easily amended than the federal constitution ....").

22. Id. at 1329 n.143.

23. Of course, not all states have existed for the same amount of time. For example, unless Alaska and Hawaii were amending their respective constitutions almost as frequently as other states amend statutory provisions, one would not expect their share of the total amendments to reach the same level as one of the original thirteen states.

24. G. Alan TARR, Understanding State Constitutions 10 (1998).

25. Sanders, supra note 11 , at 142.

26. See Gary D. Robertson, Voters Approve Change to Ban Felons as Sheriff, NEws \& REC. (Greensboro, N.C.), Nov. 2, 2010, http://www.news-record.com/content/2010/11/02/article/voters_ approve_change_to_ban_felons_as_sheriff.

27. See Act of July 1, 2010, 2010-2 N.C. Adv. Legis. Serv. 24 (LexisNexis).

28. See Richard Craver, Voters OK Use of Self-Financing Bonds, WinSTON-SALEM J., Nov. 4, 
According to a 1998 scholarly appraisal, "the unamended text of the typical state constitution remains over three times as long as that of the federal Constitution."29 A comparison of North Carolina's constitution with the U.S. Constitution-including its twenty-seven amendmentsreveals that the North Carolina Constitution, at 17,082 words, is just over twice as long as the U.S. Constitution, at 7708 words. ${ }^{30}$ While word count does not necessarily translate directly into significant constitutional text, the larger size of the North Carolina Constitution is suggestive of more plentiful opportunities for litigants to make claims and for the judiciary to find guidance in resolving legal controversies. As the Supreme Court of North Carolina has explained, the North Carolina "Constitution is more detailed and specific than the federal Constitution in the protection of the rights of its citizens." 31

2004, at B1.

29. TARR, supra note 24 , at 10.

30. This comparison was made by copying each constitution's text into a Microsoft Word document and using that program's word count feature. The text of the North Carolina Constitution was copied from the North Carolina General Assembly's website. See North Carolina State Constitution, N.C. GEN. ASSEMBLY, http://www.ncga.state.nc.us/Legislation/constitution/ ncconstitution_whole.html (last visited Nov. 30, 2010). The text of the U.S. Constitution with its twenty-seven amendments was copied from the National Archives and Records Administration website. See Bill of Rights, NAT'L ARCHIVES \& RECS. ADMIN., http://www.archives.gov/ exhibits/charters/bill_of_rights_transcript.html (last visited Nov. 30, 2010); Constitution of the United States, NAT'L ARCHIVES \& RECS. ADMIN., http://www.archives.gov/exhibits/ charters/constitution_transcript.html (last visited Nov. 30, 2010); Constitution of the United States: Amendments 11-27, NAT'L ARCHIVES \& RECS. ADMIN., http://www.archives.gov/exhibits/charters/ constitution_amendments_11-27.html (last visited Nov. 30, 2010). To ensure a more accurate word count, the preamble to the Bill of Rights and notes on ratification dates and sections affected were deleted from the website text of the amendments to the U.S. Constitution. Similarly, parenthetical references to session laws were deleted from the North Carolina Constitution. The word count for the U.S. Constitution includes the attestation and names of the delegates, as well as a note on interlineations - these items are all found in the handwritten original document. See HighResolution Downloads, NAT'L ARCHIVES \& RECS. ADMIN., http://www.archives.gov/exhibits/ charters/charters_downloads.html (last visited Nov. 30, 2010).

31. Corum v. Univ. of N.C. ex rel. Bd. of Governors, 413 S.E.2d 276, 290 (N.C. 1992); see also William J. Brennan, Jr., State Constitutions and the Protection of Individual Rights, 90 HARV. L. REV. 489, 491 (1977) ("State constitutions, too, are a font of individual liberties, their protections often extending beyond those required by the Supreme Court's interpretation of federal law.”). Some argue, however, that the detailed nature of state constitutions prevents reasoned state constitutional adjudication.

Critics note that, in contrast to the concise clauses and general principles of the Federal Constitution, state constitutions are often excessively lengthy and filled with excruciating detail. The critics contend that these characteristics of state constitutions render reasoned, principled interpretation of the documents very difficult. Furthermore, the objection runs, the haphazard organization and multifarious content of state constitutions demonstrate the influence of special interests rather than the fundamental values of the state's citizens. Finally, these critics argue, the ease and frequency with which state constitutions are amended further inhibit state courts from discerning any principles of lasting significance from the documents. 
Since state constitutions "arguably embod[y] the aims and aspirations of the state[s'] citizenry,"32 —aims and aspirations which may shift more quickly than those of the entire country - the greater length of the constitutional text and the higher frequency of amendments are not surprising. Discussing the language of the North Carolina Constitution, a former chief justice of the Supreme Court of North Carolina noted " $t \mathrm{t}] \mathrm{he}$ language is richer, more detailed, and more specific."33 He went on to characterize its detail: "How much more fertile the ground in these richly detailed grants of individual liberties than in the mere prohibitions against abridgement of them found in the federal document." 34

This combination of greater detail and increased responsiveness in North Carolina's constitution provides a potentially "fertile ground" for litigants to plant their claims. The frequency with which litigants have done so is the subject of the next section.

\section{B. Recent Trends in Reliance on the North Carolina Constitution}

Commentators look to Justice Brennan's 1977 Harvard Law Review article $^{35}$ as both noting and encouraging a reawakening in state constitutional adjudication across the country. ${ }^{36}$ State constitutional

James D. Heiple \& Kraig James Powell, Presumed Innocent: The Legitimacy of Independent State Constitutional Interpretation, 61 ALB. L. REV. 1507, 1514-15 (1998) (footnotes omitted) (citing James A. Gardner, The Failed Discourse of State Constitutionalism, 90 Mich. L. REV. 761, 818-20 (1992); James A. Gardner, Reply, What Is a State Constitution?, 24 RUTGERS L.J. 1025, 1027 (1993); Paul W. Kahn, State Constitutionalism and the Problems of Fairness, 30 VAL. U. L. REV. 459, 470-71 (1996)). For further discussion of the detail found in the North Carolina Constitution, see infra notes 33-34 and accompanying text.

32. TARR, supra note 24, at 3; see also Heiple \& Powell, supra note 31, at 1511 (“[A] state court's decision applies only within a single state, and because it is based on that state's laws and judicial precedents, is more likely to comport with the views of the citizens it affects.").

33. James G. Exum, Jr., Dusting Off Our State Constitution, N.C. ST. B. Q., Spring 1986, at 6,

34. Id. at 6.

35. Brennan, supra note 31.

36. See, e.g., Ruth V. McGregor, Tribute, Recent Developments in Arizona State Constitutional Law, 35 ARIz. ST. L.J. 265, 265 (2003) (“Although state courts had previously looked to their own constitutions to resolve questions of individual rights, Justice Brennan's article awakened increased interest in state constitutions as independent sources of such rights.”); Randall T. Shepard, The Maturing Nature of State Constitution Jurisprudence, 30 VAL. U. L. REV. 421, 421, 424 (1996) ("One need not search very far to find that scholarly literature regularly credits Justice Brennan with launching the renewal of state constitutional law.... [But m]ore important to the world of day-byday litigation, state courts exercised their constitutional authority in a variety of settings well before Justice Brennan's exhortation."). In the late 1970s and early 1980s, "the interest in state supreme courts and state constitutional law experienced a remarkable reawakening." Acker \& Walsh, supra note 21, at 1313. "The Supreme Court has repeatedly acknowledged the state courts' authority to recognize individual liberties under the aegis of state constitutional interpretation. These liberties 
adjudication has arguably existed for the entirety of each state's history, ${ }^{37}$ although the passage of the Thirteenth, Fourteenth, and Fifteenth Amendments certainly deemphasized the role of states in the protection of individual rights. In the elegant summary of one author:

Despite the strong assertion of national power evident in Justice Story's opinion in Martin v. Hunter's Lessee, the state courts retained their sovereign position as primary guarantors of the people's civil liberties. After all, the federal Constitution, with its narrowly defined scope, did not address the rights of state citizens, but only federal citizens. So it worked, unquestioned in practice if not in theory, until the Reconstruction Era following the Civil War. This time period, often referred to as the "vast transformation," saw a tremendous metamorphosis in both the conception and role of the federal Constitution as a vehicle for protecting people from state actions that denied them liberties. Indeed, the effect of the passage of the Civil War amendments was not lost on those in Congress who lobbied for their passage. Cognizant of the sweeping changes in our federal system that the amendments would likely bring about, the drafters and supporters of the amendments forged ahead nonetheless because of the belief that the states had, in many cases, abdicated their responsibilities and duties. $^{38}$

While not discounting the importance of the historical state constitutional adjudications both before and after the Reconstruction amendments, this Article's focus is within the "renaissance" period beginning in the 1970s. ${ }^{39}$

may extend beyond the umbrella of federal constitutional protections. State courts have extended them in approximately four hundred cases since $1970 \ldots$..." Id. (footnotes omitted).

37. See, e.g., Bayard v. Singleton, 1 N.C. (Mart.) 5, 6-7 (1787); see also Paul H. Anderson \& Julie A. Oseid, A Decision Tree Takes Root in the Land of 10,000 Lakes: Minnesota's Approach to Protecting Individual Rights Under Both the United States and Minnesota Constitutions, 70 ALB. L. REV. 865, 877-78 (2007) (“There is some dispute about whether this 'new judicial federalism' is really all that new. Some scholars suggest that state constitutions always offered greater protection for individual rights. But other scholars contend that our modern concept of individual rights originated in Supreme Court interpretations of the Federal Constitution and, thus, required federal individual rights interpretation before the states could develop their own individual rights jurisprudence.” (footnote omitted)).

38. Jennifer DiGiovanni, Justice Charles M. Leibson and the Revival of State Constitutional Law: A Microcosm of a Movement, 86 KY. L.J. 1009, 1012-13 (1998) (footnotes omitted).

39. See Anderson \& Oseid, supra note 37, at 877 ("A renaissance of judicial federalism began in the 1970s. Some commentators have indicated that this renaissance started as the result of a perceived retrenchment by the United States Supreme Court on individual rights during the Warren E. Burger era (1969-86), which followed the more progressive Earl Warren era (1953-69). During this period of retrenchment, some state courts looked to their own constitutions to either maintain or provide greater protection for individual rights." (footnotes omitted)). 
Although an exhaustive survey of North Carolina state constitutional adjudications is beyond the scope of this Article, a cursory search of legal databases reveals a trend of increased reliance. The year 1970 was chosen as the starting date for the search, as it marks the beginning of a decade and is close in time to 1971, the year when the current constitution took effect. ${ }^{40}$ The data shown in Figure 1 below was gathered by conducting searches on both Westlaw and LEXIS for citations to the North Carolina Constitution in opinions issued by the Supreme Court of North Carolina. ${ }^{41}$

\section{Figure 1: North Carolina State "Constitutional" Cases as Revealed by a Citation Search}
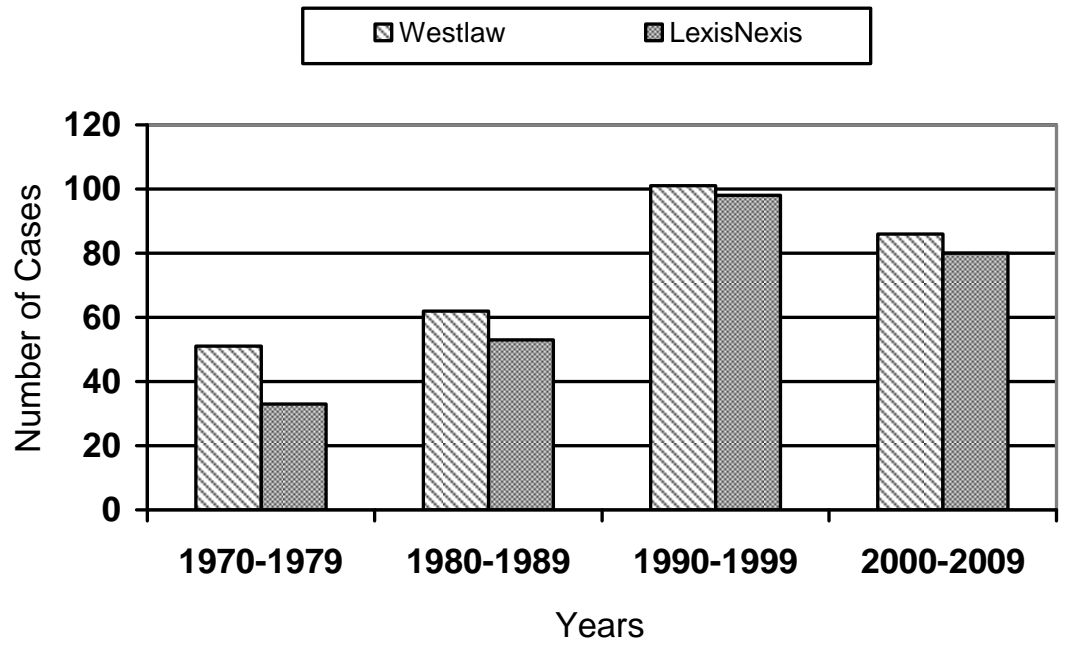

As Figure 1 shows, citations to the North Carolina Constitution have increased since the 1970s. Not all of these cases necessarily involve lengthy state constitutional adjudications. For example, approximately

40. Sanders, supra note 11 , at 144 .

41. The search method was perfected through trial and error. Initially disparate results between LEXIS and Westlaw were resolved by restricting the search to the text of the opinion itself and including "N.C.Const" (without a space) in both searches. The final search language used on October 12, 2010 was: (1) Westlaw: da(after 12/31/1969) \& co(high) \& op(“n.c. const." “n.c.const.”); (2) LEXIS: COURT(Supreme) and OPINION(“N.C. Const.” or "N.C.Const.”) and a date between $1 / 1 / 1970$ and 10/12/2010. The results were then restricted to the relevant decades to calculate the number of cases shown in Figure 1. 
ten percent of the citations to the North Carolina Constitution are made in the same sentence as citations to the U.S. Constitution, usually in the resolution of a criminal appeal. ${ }^{42}$ The following citation is representative of these types of cases: "The Fourth Amendment protects the right of the people to be secure in their persons, houses, papers, and effects, against unreasonable searches and seizures. U.S. Const. amend. IV; see also N.C. Const. art. I, $\S \S 18,19,23 .{ }^{43}$ Nonetheless, the fact that the Supreme Court of North Carolina is more frequently citing the North Carolina Constitution for support-whether independently or as part of an in-depth state constitutional adjudication-indicates an increased awareness of the potential value of the state constitution.

In his 1977 article encouraging reliance on state constitutional provisions, Justice Brennan wrote that it was "not easy to pinpoint why state courts [were]... beginning to emphasize the protections of their states' own bills of rights." ${ }^{44}$ He then went on to suggest that the reliance on state constitutions was a reaction to the U.S. Supreme Court's reluctance to further extend constitutional protections of individual rights. $^{45}$

As a practical and procedural matter, the frequency of state constitutional adjudications ultimately rests with the bar. If a plaintiff's attorney does not include state constitutional claims in a complaint, they are extremely unlikely to materialize at trial or on appeal. If an appellate defender arguing error in a criminal trial does not elaborate state constitutional grounds for the appeal, they may be waived and are not likely to be considered by the courts. In the words of former Chief Justice Exum of the Supreme Court of North Carolina, "[o]ne of the tasks of advocacy is to raise the level of consciousness of those the advocate is trying to persuade.... So it is with state constitutional law. The level of the court's consciousness about it can be raised. Lawyers

\footnotetext{
42. A search within the Westlaw results for "U.S. Const." within the same sentence as "N.C. Const." indicates that 30 of the 309 total cases include such "parallel constitutional" citations. A similar search in LEXIS revealed that 27 of the 270 total cases include parallel constitutional citations. While some of these cases with parallel constitutional citations may engage in comprehensive analysis of the North Carolina Constitution, the result is suggestive. This result also comports with the general observations made during a brief read through a random selection of these cases.

43. State v. Wiley, 565 S.E.2d 22, 32 (N.C. 2002); see also State v. Canady, 559 S.E.2d 762, 768 (N.C. 2002) ("A defendant in a criminal proceeding has the constitutional right to confront his accusers and the witnesses against him. U.S. Const. amend. VI; N.C. Const. art. I, §§ 19, 23 (2000).”).

44. Brennan, supra note 31, at 495.

45. See id. at 494-95.
} 
are the ones to raise it." ${ }^{46}$ In his 1977 article, Justice Brennan also "suggest[ed] to the bar that, although in the past it might have been safe for counsel to raise only federal constitutional issues in state courts, plainly it would be most unwise these days not also to raise the state constitutional questions." 47 The words of these justices ring true today. While state constitutional claims end in the courts, they begin with the practicing bar.

\section{Models of State Constitutional Adjudication and North Carolina's Approach}

Once state constitutional matters arrive in the courts, the method of analysis applied by the courts becomes the most pertinent issue. The generally accepted schema for constitutional decisions of state appellate courts consists of four interrelated models-primacy, interstitial, dual sovereignty, and lockstep-that characterize a state's interpretation of its constitution relative to federal interpretations of identical or analogous provisions of the U.S. Constitution. ${ }^{48}$ The primacy model recognizes the

46. Exum, supra note 33, at 9; see also State v. Bryant, 614 S.E.2d 479, 485 (N.C. 2005) ("Although this Court has previously reserved the right to grant Section 19 relief against unreasonable and arbitrary state statutes in circumstances where relief might not be obtainable under the Fourteenth Amendment to the United States Constitution, we note that defendant does not seek independent relief under the Law of the Land Clause." (emphasis added) (citation and internal quotation marks omitted)); Acker \& Walsh, supra note 21, at 1311 ("State courts' reliance upon state law to resolve issues that also present federal questions is, in one sense, neither new nor innovative. It is a stratagem, however, that was all but forgotten by one generation of lawyers, and not learned by another, in the midst of the Warren Court's nationalization of Federal Bill of Rights protections during the 1960s.” (emphasis added)).

47. Brennan, supra note 31, at 502; see also McGregor, supra note 36, at 279 ("If Arizona is to continue its progress toward developing a coherent approach to state constitutional law and find a way to apply that approach consistently, regardless of which state constitutional provision is at issue, the courts require the assistance of lawyers." (emphasis added)). Then-Vice Chief Justice McGregor goes on to quote then-Judge Souter's special concurrence in State v. Bradberry:

It is the need of every appellate court for the participation of the bar in the process of trying to think sensibly and comprehensively about the questions that the judicial power has been established to answer. Nowhere is the need greater than in the field of State constitutional law, where we are asked so often to confront questions that have already been decided under the National Constitution. If we place too much reliance on federal precedent we will render the State rules a mere row of shadows; if we place too little, we will render State practice incoherent. If we are going to steer between these extremes, we will have to insist on developed advocacy from those who bring the cases before us.

Id. at 279-80 (quoting State v. Bradberry, 522 A.2d 1380, 1389 (N.H. 1986) (Souter, J., concurring specially)).

48. See, e.g., TARR, supra note 24, at 180-85 (discussing the "lockstep," "primacy," and "interstitial" approaches); Acker \& Walsh, supra note 21, at 1315-19 (characterizing the models as "lockstep" or "equivalence," "primacy," "interstitial” or "supplemental," and "dual sovereignty”); Anderson \& Oseid, supra note 37, at 878-86 (describing and critiquing the four approaches); James 
state constitution as a fundamental source of rights and accordingly begins analysis with provisions from the state constitution. ${ }^{49}$ The interstitial model views U.S. constitutional rights as minimal and seeks supplementation from the interstices when the federal right does not resolve the claim or where the state constitution has more expansive language. $^{50}$ Under the dual-sovereignty model, both constitutions are analyzed more or less simultaneously. ${ }^{51}$ The lockstep model construes state constitutional provisions identically with analogous provisions in the U.S. Constitution. ${ }^{52}$

The approach of the Supreme Court of North Carolina is best characterized as lockstep, with some notable exceptions, two of which are the subject of this Article. As an example, in the realm of due process, the North Carolina Constitution's law of the land clause provides: "No person shall be taken, imprisoned, or disseized of his freehold, liberties, or privileges, or outlawed, or exiled, or in any manner deprived of his life, liberty, or property, but by the law of the land."53 Despite textual difference between the state and U.S. constitutions, the courts of North Carolina have repeatedly held that "'law of the land' as used in Article I, Section 19, of the Constitution of North Carolina, is synonymous with 'due process of law' as used in the Fourteenth

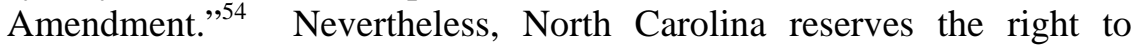

A. Gardner, State Constitutional Rights as Resistance to National Power: Toward a Functional Theory of State Constitutions, 91 GEO. L.J. 1003, 1054-58 (2003) (discussing the "primacy" and "interstitial" models as the two main viewpoints and criticizing them for being "unhelpfully rigid" and for failing to take account of the complexity of interaction between states and the federal government); Randy J. Holland, State Constitutions: Purpose and Function, 69 TEMP. L. REV. 989, 1004 (1996) (briefly describing the four approaches); Tracey Levy, Rediscovering Rights: State Courts Reconsider the Free Exercise Clauses of Their Own Constitutions in the Wake of Employment Division v. Smith, 67 TEMP. L. REv. 1017, 1032-50 (1994) (examining the four approaches in the context of free exercise claims).

49. See, e.g., TARR, supra note 24, at 183-85; Holland, supra note 48, at 1004. For a defense of the primacy approach, see generally Heiple \& Powell, supra note 31.

50. See, e.g., TARR, supra note 24, at 182-83; Holland, supra note 48, at 1004.

51. See, e.g., Holland, supra note 48, at 1004

52. See, e.g., TARR, supra note 24 , at 180-81; Holland, supra note 48, at 1004 . The lockstep model can be a result of explicit constitutional provisions, express judicial adoption, or implicit judicial adoption. See Acker \& Walsh, supra note 21, at 1316; see also FLA. CONST. art. I, § 12 ("This right shall be construed in conformity with the 4th Amendment to the United States Constitution, as interpreted by the United States Supreme Court.”).

53. N.C. CONST. art. I, § 19.

54. Rhyne v. K-Mart Corp., 594 S.E.2d 1, 15 (N.C. 2004); see also Tri-Cnty. Paving, Inc. v. Ashe Cnty., 281 F.3d 430, 435 n.6 (4th Cir. 2002) ("North Carolina courts have consistently interpreted the due process and equal protection clauses of the North Carolina Constitution as synonymous with their Fourteenth Amendment counterparts.”). 
deviate from this lockstep analysis at any point. ${ }^{55}$ This has occurred at least once in the area of criminal procedure. ${ }^{56}$

The lockstep model—as implemented by courts in North Carolina and elsewhere-has, unsurprisingly, both critics and supporters. Critics contend that lockstep analysis "submerges" state constitutional adjudication "utterly into federal jurisprudence."57 Further, lockstep analysis "is inconsistent with the nation's commitment to dual constitutionalism" because state courts have a duty to interpret their state constitution and "cannot legitimately delegate that responsibility to the Supreme Court by binding themselves to its rulings." 58 When state courts engage in such a binding lockstep analysis, they fail to provide the “'double security' for rights" that is part of our federal system. ${ }^{59}$

To the extent that these criticisms are directed at state courts that mechanically adopt federal interpretations, they seem appropriate. But such criticisms do not necessarily apply to North Carolina's lockstep approach, which considers federal authorities persuasive—not binding.

55. See Bulova Watch Co. v. Brand Distribs. of N. Wilkesboro, Inc., 206 S.E.2d 141, 146 (N.C. 1974) (" $[I] n$ the construction of the provision of the State Constitution, the meaning given by the Supreme Court of the United States to even an identical term in the Constitution of the United States is, though highly persuasive, not binding upon this Court.”); see also State v. Jackson, 503 S.E.2d 101, 104 (N.C. 1998) ("In construing the North Carolina Constitution, this Court is not bound by the decisions of federal courts, including the United States Supreme Court. However, we give the most serious consideration to those decisions, and in our discretion we may conclude that the reasoning of such decisions is persuasive.” (citation and internal quotations marks omitted)).

56. Compare State v. Welch, 342 S.E.2d 789, 795 (N.C. 1986) ("Therefore, on the basis of the Leon-Sheppard good-faith exception to the exclusionary rule, we conclude that the trial court did not err on these facts by admitting evidence resulting from the taking of the sample of the defendant's blood."), and id. at 796 (Exum, J., concurring) ("I agree that under the decisions of the United States Supreme Court relied on by the majority this Court must apply the 'good faith' exception to the exclusionary rule in determining admissibility of evidence unconstitutionally seized under the Fourth and Fourteenth Amendments to the United States Constitution.... The parties have not argued whether this exception may sustain admissibility under the North Carolina Constitution. My concurrence in the Court's opinion is based on my understanding that the opinion neither addresses nor answers this question.”), with State v. Carter, 370 S.E.2d 553, 554 (N.C. 1988) (“This case presents us with the question of whether there is a good faith exception under article I, section 20 of the North Carolina Constitution to the exclusion of evidence obtained by unreasonable search and seizure. We hold that there is no good faith exception to the requirements of article I, section 20 as applied to the facts of this case ....”).

57. Randall T. Shepard, The Renaissance in State Constitutional Law: There Are a Few Dangers, but What's the Alternative?, 61 ALB. L. REV. 1529, 1550 (1998) (“One alternative, of course, is stalwart, lockstep adherence to the jurisprudence of the Federal Constitution. I have already stated my distrust of this 'solution' to the problems of state constitutionalism and I continue to believe that for state courts to submerge utterly into federal jurisprudence is both unwise and invalid as a matter of history and legal analysis." (footnote omitted)).

58. TARR, supra note 24 , at 181.

59. Id. 
Supporters of lockstep analysis acknowledge this division between "binding lockstep" and "persuasive lockstep." While the ultimate determination of legal rights might be the same in many cases, persuasive lockstep analysis leaves the door open for a state court to diverge from federal jurisprudence. One supporter of lockstep analysis expresses the notion of persuasive lockstep as follows:

Lockstep analysis, one might say, does not necessarily reveal an abandonment by state courts of their responsibilities to protect liberty and to reflect meaningfully upon the best ways to do so. On the contrary, it might well represent a discharge of those responsibilities, but in circumstances where the state court feels that the national government is already doing a reasonably good job. In those circumstances, a state court might reasonably conclude that there is no need, at least for the moment, to explore in any greater depth the possibilities presented by the state constitution to protect liberty any more or less vigorously than it is already protected by the national judicial analysis. Lockstep analysis thus need not represent an absence of independent constitutional judgment; it can just as easily represent the outcome of a fully-informed exercise of independent state judicial judgment. $^{60}$

Jeffrey Usman helpfully catalogs the arguments made by supporters of lockstep analysis:

Advocates of state court adherence to federal precedent (1) question whether states are really distinct political communities with divergent identities, (2) assert the importance of national values to constitutional interpretation, (3) note that many state provisions are modeled on the Federal Constitution, (4) suggest reliance preserves judicial resources by allowing state courts to tap into a huge volume of decisions addressing the requirements of the Federal Constitution, (5) caution that reliance avoids varying mandates that could be confusing for state officials, and (6) claim that reliance fosters judicial restraint. ${ }^{61}$

Critics of lockstep analysis arguably acknowledge the legitimacy of persuasive lockstep analysis, as exemplified by Professor Tarr:

In undertaking this independent inquiry, a state court may of course consult how the Supreme Court has interpreted analogous federal

60. Gardner, supra note 48, at 1061.

61. Jeffrey Omar Usman, Good Enough for Government Work: The Interpretation of Positive Constitutional Rights in State Constitutions, 73 ALB. L. REV. 1459, 1493-94 (2010). 
provisions, just as it may consult how other state courts have interpreted their counterpart guarantees. But if a state court decides to conform its interpretation of a state provision to the Supreme Court's interpretation of an analogous federal provision, this decision has to be based on the persuasiveness of the Court's argument rather than on the Court's position in the legal hierarchy. ${ }^{62}$

Setting aside a more thorough examination of the drawbacks and benefits of persuasive lockstep, the fact remains that the Supreme Court of North Carolina has typically followed this form of analysis. ${ }^{63}$ The opinions in which North Carolina's highest court has followed U.S. Supreme Court rulings - while they may include rationales that diverge slightly from the federal rationale for the rule-do not provide much opportunity for analyzing North Carolina's unique place among the courts of this country. But the Supreme Court of North Carolina has stepped "out of lockstep" in several cases to address an exclusively state constitutional matter or interpret a state constitutional provision differently. ${ }^{64}$ In two of these cases, the court has adopted intermediate scrutiny as a resolution to the constitutional conflict. ${ }^{65}$

\section{INTERMEDIATE SCRUTINY IN NORTH CAROLINA}

\section{A. Intermediate Scrutiny in Federal and Other State Courts}

As typically phrased by the U.S. Supreme Court, the intermediate scrutiny test asks whether a statutory classification is "substantially related to an important governmental objective." 66 If not, the classification is unconstitutional. ${ }^{67}$ While the test for intermediate scrutiny is easy to state, its application in various cases has not led to the development of a crisp, bright-line rule. Rather, the application of intermediate scrutiny has varied between cases, as have applications of strict scrutiny and rational basis review. As legal scholars have

62. TARR, supra note 24 , at 182.

63. See supra notes 53-56 and accompanying text.

64. For those cases where there is no analogous federal precedent, some would argue the departure from lockstep analysis is unavoidable. See Usman, supra note 61, at 1494 ("The interpretation of positive constitutional rights in state constitutions is a significantly different enterprise than interpreting negative rights under state constitutions if for no other reason than state courts do not have the smothering security blanket of federal precedent on which to hold tightly.").

65. See infra Part III.B-C.

66. Clark v. Jeter, 486 U.S. 456, 461 (1988).

67. See id. 
repeatedly noted, "the degree of judicial skepticism or deference varies considerably within levels of scrutiny."68 Speaking generally, the most that can be said with certainty is that intermediate scrutiny simply falls somewhere "in between" rational basis review and strict scrutiny. ${ }^{69}$

The flexibility in the intensity of review under intermediate scrutiny has made it a useful tool within the federal court system. In addition to its well-known use for classifications based on gender and legitimacy, ${ }^{70}$ intermediate scrutiny has been applied to in-between claims where underlying constitutional rights are qualified in some fashion. A good example of such an application of intermediate scrutiny can be seen in the Fourth Circuit's determination of the appropriate standard for a challenge to a curfew for minors:

Initially we must consider the level of scrutiny appropriate to this case. Plaintiffs contend that the ordinance infringes minors' constitutional liberties and therefore should be subject to strict scrutiny. It is true that a child, merely on account of his minority, is not beyond the protection of the Constitution. Minors enjoy some rights under the First and Fourteenth Amendments before they attain adulthood. At the same time, the Supreme Court has made abundantly clear that children's rights are not coextensive with those of adults. Traditionally at common law, and still today, unemancipated minors lack some of the most fundamental rights of self-determination-including even the right of liberty in its narrow sense, i.e., the right to come and go at will.

In recognition of these customary limitations, the state's authority over children's activities is broader than over like actions of adults.

68. E.g., Kim Shayo Buchanan, The Sex Discount, 57 UCLA L. REv. 1149, 1169 \& n.148 (2010) (comparing U.S. Supreme Court opinions with differing applications of strict scrutiny, intermediate scrutiny, and rational basis review); see also Jack M. Balkin, Plessy, Brown, and Grutter: A Play in Three Acts, 26 CARDOzo L. REV. 1689, 1727 (2005) ("Not only has strict scrutiny become less than strict in Grutter, but the rational basis test has become stricter to protect groups like the mentally retarded, the children of illegal immigrants, and homosexuals. The Court introduced a medium level of scrutiny in its sex equality cases in the 1970s, and then began applying it in novel ways in the First Amendment area in the 1990s." (footnotes omitted)); Trina Jones, Response, Anti-Discrimination Law in Peril?, 75 Mo. L. REv. 423, 437 (2010) (“At times the Court has applied a more robust version of rational basis review, and at times it has applied a more robust version of intermediate scrutiny. Moreover, strict scrutiny has produced different outcomes in comparable cases." (footnotes omitted)).

69. See, e.g., H.B. Rowe Co. v. Tippett, 615 F.3d 233, 242 (4th Cir. 2010) (“[I]ntermediate scrutiny requires less of a showing than does 'the most exacting' strict scrutiny standard of review.”).

70. Clark, 486 U.S. at 461 ("Between these extremes of rational basis review and strict scrutiny lies a level of intermediate scrutiny, which generally has been applied to discriminatory classifications based on sex or illegitimacy.”). 
State laws do not permit children to drive a car before they reach a certain age. Compulsory attendance laws require children to attend school. Labor laws limit the opportunities of children to engage in gainful employment. These types of laws reflect the state's general interest in youth's well being.

In light of the case law, two things seem clear. First, children do possess at least qualified rights, so an ordinance which restricts their liberty to the extent that this one does should be subject to more than rational basis review. Second, because children do not possess the same rights as adults, the ordinance should be subject to less than the strictest level of scrutiny. We thus believe intermediate scrutiny to be the most appropriate level of review and must determine whether the ordinance is substantially related to important governmental interests. ${ }^{71}$

Like their federal counterparts, state courts have applied intermediate scrutiny to the familiar categories of gender and legitimacy. ${ }^{72}$ In addition, state courts have applied intermediate scrutiny to challenges based on state constitutional rights that have been qualified in some fashion. $^{73}$ State courts have sometimes modified the phrasing of the intermediate scrutiny standard. For example, in the context of an involuntary civil commitment proceeding, the Supreme Court of New Hampshire observed: "In considering an equal protection challenge under our State Constitution,... [c]lassifications involving important substantive rights must be reasonable and rest upon some ground of difference having a fair and substantial relation to the object of the

71. Schleifer ex rel. Schleifer v. City of Charlottesville, 159 F.3d 843, 846-47 (4th Cir. 1998) (emphases added) (citations and internal quotation marks omitted).

72. See, e.g., People v. Botruff, 817 N.E.2d 463, 469 (Ill. 2004) (“Intermediate scrutiny applies to discriminatory classifications based on sex or illegitimacy.”); Salaiscooper v. Eighth Judicial Dist. Court ex rel. Cnty. of Clark, 34 P.3d 509, 517 (Nev. 2001) (indicating intermediate scrutiny applies to a claim of gender discrimination pursued under the Nevada and United States constitutions); Dep't of Transp. v. Rowe, 549 S.E.2d 203, 207 (N.C. 2001) (recognizing U.S. Supreme Court cases that held that "[o]ther classifications, including gender and illegitimacy, trigger intermediate scrutiny.”); State v. Thompson, 95 Ohio St. 3d 264, 2002-Ohio-2124, 767 N.E.2d 251, at 13 ("When a discriminatory classification based on sex or illegitimacy is at issue, we employ heightened or intermediate scrutiny and require that the classification be substantially related to an important governmental objective.”).

73. See, e.g., Soloco, Inc. v. Dupree, 97-1256, p. 4 (La. 1/21/98); 707 So. 2d 12, 15 (“[Under the Louisiana Constitution, a]n intermediate level of scrutiny is reserved for laws which classify persons on the basis of birth, age, sex, culture, physical condition, or political ideas or affiliation.”); Davis v. Union Pac. R.R., 937 P.2d 27, 31 (Mont. 1997) (Regnier, J., plurality opinion) (“Middle-tier scrutiny has been used in limited situations, including those where the rights at issue have some origin in the Montana Constitution, such as welfare, but are not found in the Declaration of Rights.”). 
legislation."74 The court went on to note that it had "applied this 'intermediate review' to a broader category of rights than do the federal courts, although [its] analysis when applying this level of review is the same."75 In other words, it seems New Hampshire has applied intermediate scrutiny to more rights and-even though phrased differently-it applies the federal test.

State courts, in interpreting state constitutional provisions, are free to diverge from the methods of constitutional analysis applied by the federal courts. $^{76}$ When conducting state constitutional analysis, state courts generally encounter two types of claims: (1) those where there is a parallel provision in the U.S. Constitution and (2) those where the state constitution is the only basis for the claim. In the first category, federal interpretations of the U.S. Constitution provide a floor for a variety of rights, ${ }^{77}$ although states are free to interpret their state constitutions to provide more protections to those rights than the U.S. Constitution does. $^{78}$ In the second category, states are generally free from federal jurisprudential constraints. ${ }^{79}$

74. In re Sandra H., 846 A.2d 513, 517 (N.H. 2004) (citations and internal quotation marks omitted).

75. Id.

76. See Exum, supra note 33, at 8 ("Under its own state constitution, a state court is not bound by constructs of constitutional doctrines used by the United States Supreme Court.”).

77. See State v. Jackson, 503 S.E.2d 101, 103 (N.C. 1998) (“[B]ecause the United States Constitution is binding on the states, the rights it guarantees must be applied to every citizen by the courts of North Carolina, so no citizen will be 'accorded lesser rights' no matter how we construe the state Constitution....[T]he United States Constitution provides a constitutional floor of fundamental rights guaranteed all citizens of the United States, while the state constitutions frequently give citizens of individual states basic rights in addition to those guaranteed by the United States Constitution."). At least two scholars have noted the impreciseness of the "federal floor" metaphor in the area of criminal procedure. See Marc L. Miller \& Ronald F. Wright, Leaky Floors: State Law Below Federal Constitutional Limits, 50 ARIz. L. REV. 227, 229-30 (2008) ("In the area of criminal procedure there are myriad state court decisions, statutes, rules, and practices that are sometimes more restrictive and sometimes more generous with respect to civil liberties and government authority than their federal counterparts. Surveying the full range of topics within the field of criminal procedure it is common to find state positions both above and below the federal constitutional 'floor.'” (footnotes omitted)).

78. See Brennan, supra note 31, at 502 \& n.83 (noting that the Supreme Court has made clear numerous times that its "decisions ... are not, and should not be, dispositive of questions regarding rights guaranteed by counterpart provisions of state law”); see also Oregon v. Hass, 420 U.S. 714, 719 (1975) ("[A] State is free as a matter of its own law to impose greater restrictions on police activity than those this Court holds to be necessary upon federal constitutional standards.”); Cooper v. California, 386 U.S. 58, 62 (1967) (“Our holding, of course, does not affect the State's power to impose higher standards ... than required by the Federal Constitution if it chooses to do so.").

79. See Jackson, 503 S.E.2d at 103-04 ("States remain free to interpret their own constitutions in any way they see fit, including constructions which grant a citizen rights where none exist under the federal Constitution.” (citing Lowe v. Tarble, 329 S.E.2d 648, 650 (N.C. 1985))). 
Blankenship and King involved interpretations of the North Carolina Constitution to provide greater rights than are found under the U.S. Constitution. Representing the first category of state constitutional adjudications, Blankenship interpreted the state equal protection clause to find greater rights for voters than exist under the federal counterpart. ${ }^{80}$ King, on the other hand, addressed an exclusively state constitutional matter - the extent of the state constitutional right to education for longterm suspended students. ${ }^{81}$ Both cases involved the application of state constitutional intermediate scrutiny.

\section{B. Blankenship v. Bartlett}

The legislative redistricting that occurs soon after each national census frequently leads to challenges in state and federal courts. ${ }^{82}$ North Carolina is no exception. The challenges to legislative redistricting brought in the 1960s, 1980s, and 1990s were all filed in or successfully removed to federal court. ${ }^{83}$ But the challenge to the 2000 redistricting was resolved by the Supreme Court of North Carolina in Stephenson v. Bartlett. $^{84}$ The challenge involved "a state law question of first impression"-whether the state legislature had violated the whole-county provisions $^{85}$ of the state constitution when it enacted the 2001 legislative redistricting plans. ${ }^{86}$

The plaintiffs, who were North Carolina registered voters, argued that the whole-county provisions prevented the General Assembly from dividing counties in creating legislative districts, "except to the extent necessary to comply with federal law." ${ }^{87}$ The defendants—-the board of

80. See infra Part III.B.

81. See infra Part III.C.

82. See Pamela S. Karlan, Politics by Other Means, 85 VA. L. REV. 1697, 1719 (1999) (“After the 1980 census, 'roughly one-third of all redistricting was done either directly by federal courts or under the injunctive authority of the courts,' and the post-1990 round saw at least forty-one states in court over at least one of their apportionments." (footnote omitted) (quoting Samuel Issacharoff, Judging Politics: The Elusive Quest for Judicial Review of Political Fairness, 71 TEx. L. REV. 1643, 1689-90 (1993))).

83. See Shaw v. Barr, 808 F. Supp. 461, 463 (E.D.N.C. 1992), rev'd, 509 U.S. 630 (1993); Cavanagh v. Brock, 577 F. Supp. 176, 178 (E.D.N.C. 1983); Drum v. Seawell, 249 F. Supp. 877, 879 (M.D.N.C. 1965).

84. Stephenson v. Bartlett (Stephenson I), 562 S.E.2d 377 (N.C. 2002).

85. N.C. Const. art. II, $\S 3(3)$ ("No county shall be divided in the formation of a senate district...."); id. $\S 5(3)$ ("No county shall be divided in the formation of a representative district....").

86. Stephenson I, 562 S.E.2d at 381, 383.

87. Id. at 381. 
elections and various political leaders ${ }^{88}$ - attempted to remove the case to federal court. ${ }^{89}$ But the federal court remanded, noting that the plaintiffs had challenged the redistricting solely on state constitutional grounds. ${ }^{90}$

The Supreme Court of North Carolina found that "[t]he 2001 legislative redistricting plans violate[d] the [whole-county provisions] for reasons unrelated to compliance with federal law." ${ }^{91}$ Specifically, the court noted that 51 of 100 counties were divided by the senate redistricting plan and 70 of 100 counties were divided by the house redistricting plan. ${ }^{92}$ The court ultimately held that because the General Assembly's 2001 legislative redistricting plans divided counties without a federal law justification, the plans were unconstitutional and void. ${ }^{93}$

As part of Stephenson I, the court considered proposed remedial plans submitted by the plaintiffs. Notably, the court found that these remedial plans "implicate[d] the fundamental right to vote on equal terms, and thus strict scrutiny [was] the applicable standard." 94

On remand, the trial court found that the revised redistricting plans drawn up after the Stephenson I decision were unconstitutional. ${ }^{95}$ The Supreme Court of North Carolina affirmed, reiterating that the wholecounty provisions required the General Assembly to avoid dividing counties, except "to the extent necessary to comply with federal law, including the 'one-person, one-vote' principle and the [Voting Rights Act of 1965]." "96

The landmark Stephenson decisions-and the application of state constitutional provisions in that litigation-likely paved the way for the challenge to judicial districts in Blankenship v. Bartlett.

The plaintiffs in Blankenship challenged Wake County judicial districts that disproportionately distributed voting power in the elections for resident superior court judges. ${ }^{97}$ The General Assembly created the potential imbalance in voter strength in a 1993 statutory amendment that added a judgeship to District $10 \mathrm{~A} .^{98}$ As Table 1 shows, the challenged

\footnotetext{
88. See id. at 377.

89. See Stephenson v. Bartlett, 180 F. Supp. 2d 779, 781 (E.D.N.C. 2001).

90. See id. at 786.

91. Stephenson I, 562 S.E.2d at 389.

92. Id. at 390.

93. See id. at 392.

94. See id. at 393.

95. Stephenson v. Bartlett (Stephenson II), 582 S.E.2d 247, 249 (N.C. 2003).

96. Id. at 251,254 .

97. See Blankenship v. Bartlett, 681 S.E.2d 759, 761-62 (N.C. 2009).

98. See id. at 761 .
} 
judicial districts granted residents in District 10A approximately four to five times more voting power than residents in the other three districts. ${ }^{99}$

Table 1: Distribution of Voters Among Judicial Districts Challenged in Blankenship ${ }^{100}$

\begin{tabular}{|c|c|c|c|}
\hline $\begin{array}{c}\text { Superior } \\
\text { Court } \\
\text { District }\end{array}$ & Residents & $\begin{array}{c}\text { Number of } \\
\text { Superior Court } \\
\text { Judges }\end{array}$ & $\begin{array}{c}\text { Residents per } \\
\text { Superior Court } \\
\text { Judge }\end{array}$ \\
\hline 10A & 64,398 & 2 & 32,199 \\
\hline 10B & 281,493 & 2 & 140,747 \\
\hline 10C & 158,812 & 1 & 158,812 \\
\hline 10D & 123,143 & 1 & 123,143 \\
\hline
\end{tabular}

The Supreme Court of North Carolina found that the North Carolina Constitution's equal protection clause applied to the General Assembly's creation of the District 10A judgeship. ${ }^{101}$ At the outset, the court noted that it usually follows the U.S. Supreme Court's analysis in equal protection matters, but that such analysis was not binding on the court. ${ }^{102}$ Acknowledging that federal courts had found "the 'one-person, one-vote' standard . . . inapplicable to state judicial elections," the court observed "considerable tension in the jurisprudence, as clearly illustrated by Chisom v. Roemer." "103 Reviewing Chisom and other U.S. Supreme Court decisions, the court concluded that "the [U.S.] Supreme Court has indicated both that judges are representatives and that they do not represent people." 104 This "seeming contradiction" and "fundamental tension" was central to the North Carolina Supreme Court's explanation of its holding: "Rather than wholly ignoring that tension, this Court acknowledges it by holding that our State's Equal Protection Clause requires a heightened level of scrutiny of judicial election districts."

The court also looked to federal equal protection jurisprudence addressing semi-suspect classes and quasi-fundamental rights. ${ }^{106}$ In light of this federal jurisprudence, the court continued its review of the North

\footnotetext{
99. See id.

100. This table is copied from the Blankenship opinion. See id.

101. Id.

102. Id. at 762 .

103. Id. at 763 (citing Chisom v. Roemer, 501 U.S. 380 (1991)).

104. Id.

105. See id.

106. See id. at 764-65.
} 
Carolina Constitution and found that part of the article on the judiciary guaranteed "an individual right of the people to vote in [judicial] elections." ${ }^{107}$ Reading this section with the equal protection provision, and in light of the representative aspects of state judicial office, the court held "that the right to vote in superior court elections on substantially equal terms is a quasi-fundamental right which is subject to a heightened level of scrutiny." 108

The state equal protection analysis and the quasi-fundamental right to vote under the state constitution provided the court with two frameworks to determine the applicable level of scrutiny. ${ }^{109}$ Both analyses indicated that some form of heightened scrutiny-but not strict scrutiny-should apply. ${ }^{110}$

In determining the form of "heightened scrutiny" applicable under the state equal protection clause, the court found "many important policy interests to be weighed in addition to population" and held that "strict scrutiny according to the one-person, one-vote rule is inappropriate here."111 The court provided a non-exhaustive list of policy interests that the legislature might consider in drawing judicial districts, including "geography, population density, convenience, number of citizens in the district eligible to be judges, and number and types of legal proceedings in a given area." ${ }^{112}$ With these legislative policy interests militating against strict scrutiny, the court found that the applicable scrutiny was "somewhere in between," as the following discourse indicates:

We conclude that judicial elections have a component that implicates the fundamental right to vote and a separate component that is ordinarily the province of the legislature, subject only to review for rationality by the courts. The right to vote on equal terms for representatives triggers heightened scrutiny, even as the nonrepresentative aspects inherent in the role of the judiciary preclude strict scrutiny on a one-person, one-vote standard. Thus, neither rational basis nor strict scrutiny is an appropriate standard of review.

107. Id. at 765 (citing N.C. CoNST. art. IV, § 9).

108. Id.

109. See id. at 764 ("Federal equal protection analysis provides us with another framework under which plaintiffs' claims should be decided.” (emphasis added)).

110. See id. at 763, 765 .

111. Id. at 763 .

112. Id. at 766 . 
Rather, we conclude the applicable standard lies somewhere in between. ${ }^{113}$

The court analogized the appropriate level of scrutiny of state judicial elections to the scrutiny of symbolic speech, which "combine[s] speech and non-speech elements in the same course of conduct."114 Because state judicial elections "combine representative and nonrepresentative aspects," intermediate scrutiny was the correct standard. ${ }^{115}$ Specifically, the court held that "[j]udicial districts will be sustained if the legislature's formulations advance important governmental interests unrelated to vote dilution and do not weaken voter strength substantially more than necessary to further those interests." 116

Blankenship is notable in its application of intermediate scrutiny to resolve potentially conflicting state constitutional provisions. Intermediate scrutiny serves as an elegant solution to the "fundamental tension" between judges as representatives and nonrepresentatives. In addition, Blankenship is part of a small class of cases where the Supreme Court of North Carolina has found more protection under the North Carolina Constitution than exists under the U.S. Constitution. In other words, Blankenship represents the state supreme court engaging in interstitial, or supplemental, analysis rather than falling into lockstep with federal precedent. These notable features of Blankenship are even more evident in King ex rel. Harvey-Barrow v. Beaufort County Board of Education, the subject of the next section.

C. King ex rel. Harvey-Barrow v. Beaufort County Board of Education

Similar to other states, North Carolina's constitution includes several provisions directly addressing education. ${ }^{117}$ A portion of the Declaration of Rights states that "[t]he people have a right to the privilege of education, and it is the duty of the State to guard and maintain that right."

\footnotetext{
113. Id. at 763-64 (citation omitted).

114. Id. at 765 .

115. Id. at 765-66.

116. Id. at 766 .

117. See Usman, supra note 61, at 1465 ("[E]very state constitution contains a clause expressly addressing education.”).

118. N.C. CONST. art. I, § 15.
} 
entirety of article IX to education. ${ }^{119}$ Specifically, section 2 states that "[t]he General Assembly shall provide by taxation and otherwise for a general and uniform system of free public schools, which shall be maintained at least nine months in every year, and wherein equal opportunities shall be provided for all students." 120

In San Antonio Independent School District v. Rodriguez, ${ }^{121}$ the U.S. Supreme Court decided that disparate educational funding did not violate the Equal Protection Clause of the U.S. Constitution and that education was not a fundamental right activating strict scrutiny. ${ }^{122}$ Following Rodriguez-and perhaps motivated by Justice Thurgood Marshall's suggestion in dissent ${ }^{123}$-educational-rights litigation shifted to state constitutional challenges and, in some cases, campaigns to amend state constitutions. ${ }^{124}$ The landmark North Carolina decision from this line of cases is Leandro v. State. ${ }^{125}$

The challenge to state educational funding brought in Leandro involved a somewhat complex alignment of parties, including: (1) plaintiff students and local school boards from relatively poor rural districts, (2) plaintiff-intervenors from relatively large and wealthy city school systems, and (3) the state and state board of education as defendants. ${ }^{126}$ Collectively, the plaintiffs and plaintiff-intervenors sought declaratory and injunctive relief, arguing that the constitutional right to equal educational opportunities was being denied by defendants because of funding disparities. ${ }^{127}$ The rural plaintiffs pointed to poor facilities, inadequate educational resources, low teacher salaries, and low test

\footnotetext{
119. See id. art. IX.

120. Id. § 2 .

121. 411 U.S. 1 (1973).

122. Id. at 37-38, 40, 56 .

123. Jeffrey S. Sutton, Essay, San Antonio Independent School District v. Rodriguez and Its Aftermath, 94 VA. L. REV. 1963, 1971 (2008) (noting Justice Thurgood Marshall's suggestion in a footnote to his Rodriguez dissent that "'nothing in the Court's decision today ... should inhibit further review of state educational funding schemes under state constitutional provisions"” (quoting San Antonio Indep. Sch. Dist. v. Rodriguez, 411 U.S. 1, 133 n.100 (1973) (Marshall, J., dissenting))).

124. See Usman, supra note 61, at 1469 ("Following in the wake of [the Rodriguez] decision, school related litigation shifted to state constitutional provisions. Litigation theories predominantly focused on funding disparities between districts and the adequacy of educational funding. The underlying litigation strategy was coupled with pursuit of constitutional amendments addressing issues of school quality, funding, and safety.” (footnotes omitted)). See generally Sutton, supra note 123 (tracing the background of Rodriguez and reviewing its impact on state court adjudications of educational rights).

125. 488 S.E.2d 249 (N.C. 1997).

126. Id. at $252-53$.

127. Id.
} 
scores on state and national tests. ${ }^{128}$ The urban plaintiff-intervenors claimed a disproportionate financial burden because of relatively large numbers of special-education, limited-English-proficient, and academically gifted students and argued that the burden from these students forced them to divert funding from regular education services. ${ }^{129}$

Addressing these state constitutional challenges, the Supreme Court of North Carolina held there was a fundamental right to "an opportunity to receive a sound basic education" and that this right included a qualitative component. ${ }^{130}$ The court defined "sound basic education" in great detail:

For purposes of our Constitution, a "sound basic education" is one that will provide the student with at least: (1) sufficient ability to read, write, and speak the English language and a sufficient knowledge of fundamental mathematics and physical science to enable the student to function in a complex and rapidly changing society; (2) sufficient fundamental knowledge of geography, history, and basic economic and political systems to enable the student to make informed choices with regard to issues that affect the student personally or affect the student's community, state, and nation; (3) sufficient academic and vocational skills to enable the student to successfully engage in post-secondary education or vocational training; and (4) sufficient academic and vocational skills to enable the student to compete on an equal basis with others in further formal education or gainful employment in contemporary society. ${ }^{131}$

After recognizing this state constitutional right, the court "conclude[d] that provisions of the current state system for funding schools which require or allow counties to help finance their school systems and result in unequal funding among the school districts of the state do not violate constitutional principles.",132

Leandro's recognition of a fundamental right to education proved foundational in a series of cases addressing various aspects of North Carolina's system for public education. ${ }^{133}$ The North Carolina

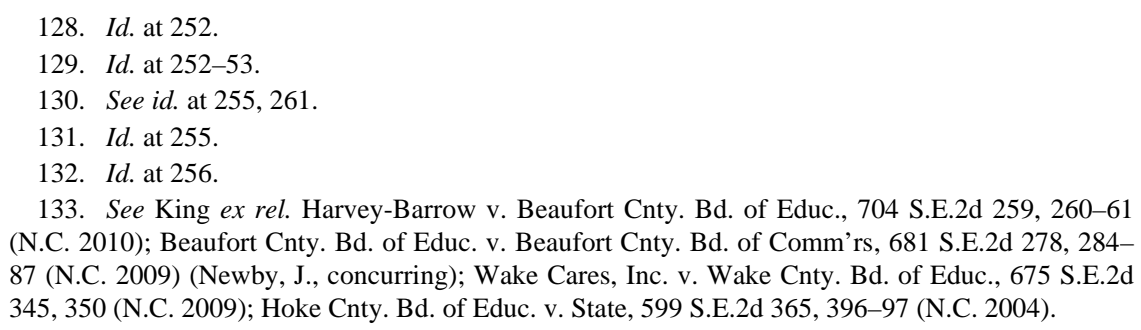


experience can be contrasted with the federal experience under Rodriguez and the experience of states that have not recognized education as a fundamental right. If education is not a fundamental right in a given legal landscape, rational basis review applies. ${ }^{134}$ Consequently, the actions of the school board, state legislature, and other actors in educational governance are much more likely to be upheld on constitutional review. But when a fundamental right is recognized, "state courts must confront the challenge.... In addressing such rights, the interpretive approaches adopted by state courts have reflected a rich diversity. But it cannot be ignored that many state courts have struggled mightily with the task." 135 One such challenge-and perhaps mighty struggle-faced the Supreme Court of North Carolina in King.

The plaintiff in King challenged the school board's denial of alternative-education services to her during her long-term suspension for fighting. ${ }^{136}$ A procedural due process hearing by a panel of central office administrators upheld the suspension, which King then challenged in superior court. ${ }^{137}$ Notably, neither the school board nor the school superintendent provided King with a reason for the denial of alternativeeducation services. ${ }^{138}$

Before the Supreme Court of North Carolina, King argued that the school board's "denial of alternative education during her long-term suspension [was] a violation of the state constitution." ${ }^{139}$ Relying on her Leandro right to a sound basic education, King urged the court "to apply strict scrutiny to [the] defendants' decision to deny her alternative education." 140

The court recognized that the intersection of school discipline and education "require[d it] to harmonize the rational basis test employed in school discipline cases with the strict scrutiny analysis that formed a part of [its] constitutional holding in school funding cases."141 In other

134. See, e.g., San Antonio Indep. Sch. Dist. v. Rodriguez, 411 U.S. 1, 40 (1973) (“A century of Supreme Court adjudication under the Equal Protection Clause affirmatively supports the application of the traditional standard of review, which requires only that the State's system be shown to bear some rational relationship to legitimate state purposes.”); Doe v. Superintendent of Schs. of Worcester, 653 N.E.2d 1088, 1097 (Mass. 1995) ("In light of our conclusion that the plaintiff does not have a fundamental right to an education under Part II, c. 5, § 2, we apply the lowest level of scrutiny, the rational basis test, to her claim . ...”).

135. Usman, supra note 61, at 1461.

136. King, 704 S.E.2d at 261.

137. Id.

138. Id. at 265.

139. Id. at 261.

140. Id. at 263.

141. Id. at 262. 
words, the Leandro court's recognition of education as a fundamental right created a constitutional conflict between discipline and education that the court had to resolve in King.

After reviewing the text of the state constitution and the statutory scheme for alternative education, the court held that there was no state constitutional right to alternative education, as alternative-education programs were statutory in origin. ${ }^{142}$ Notwithstanding the lack of a constitutional right to alternative education, the court held that a longterm suspended student does have a state constitutional right to know the reasons for exclusion from alternative education because the denial of the statutory right could potentially infringe on the state constitutional right to equal educational access. ${ }^{143}$

Having recognized a state constitutional right to an explanation, the court then considered the appropriate standard of review. ${ }^{144}$ The court reviewed precedent from within and outside of North Carolina, noting the national trend towards rational basis review of school disciplinary matters, but also acknowledging its prior application of strict scrutiny in Leandro. $^{145}$ On the one hand, the court viewed strict scrutiny as imposing "unworkable burdens ... on school administrators,... jeopardiz[ing] the safety of the greater school community and imped[ing] the educational progress of the suspended student's peers."146 "Rational basis review, on the other hand, [did] not adequately protect student access to educational opportunities or guard against arbitrary decisions or inadvertent errors by school officials."147 Having found strict scrutiny and rational basis review inappropriate, the court held that intermediate scrutiny was the applicable standard. ${ }^{148}$ According to the court, "school administrators must articulate an important or significant reason for denying students access to alternative education; however, the reasons supporting their decisions do not need to be compelling."149

As in Blankenship, ${ }^{150}$ intermediate scrutiny proved a useful solution to the constitutional conflict presented in King. Whether intermediate

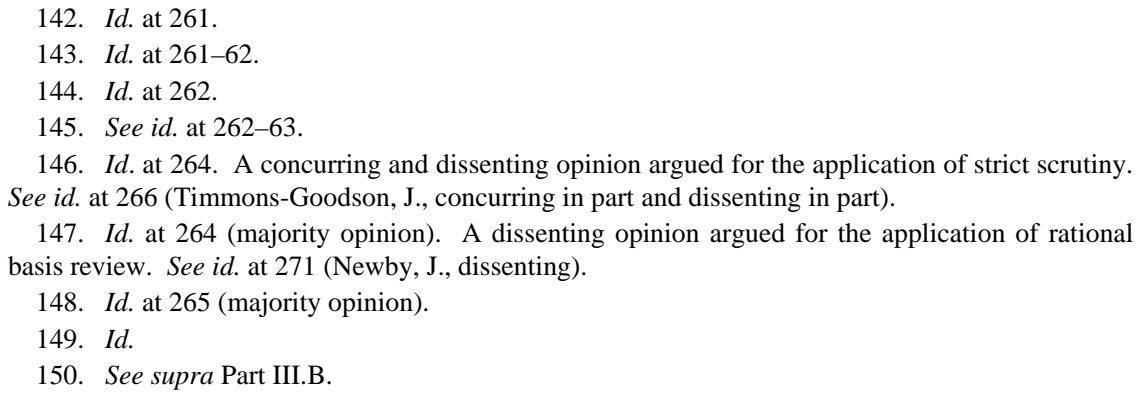


scrutiny is the best solution to the challenges brought in King and Blankenship is left for the reader to determine. The next section attempts to inform such a determination by cataloging the benefits and drawbacks of intermediate scrutiny as a standard of review.

\section{Possible Drawbacks and Benefits}

As demonstrated by the North Carolina Supreme Court's experience in King and Blankenship, intermediate scrutiny has the benefit of flexibility. Blankenship borrowed the intermediate scrutiny standard from federal law to resolve the conflict between judges as representatives and judges as neutral adjudicators. ${ }^{151}$ King then cited Blankenship for the state constitutional standard of intermediate scrutiny. ${ }^{152}$ But King firmly grounded the standard in state constitutional law and applied state-law nuances by articulating intermediate scrutiny with this language: "Under the state intermediate scrutiny standard, school administrators must articulate an important or significant reason for denying students access to alternative education; however, the reasons supporting their decisions do not need to be compelling." "153 King did not explicitly place the burden of persuasion on the state, ${ }^{154}$ as is sometimes specified with federal intermediate scrutiny. ${ }^{155}$ Both King and Blankenship made use of the flexibility of intermediate scrutiny in resolving the unique state constitutional claims brought before the court. Such flexible applications of intermediate scrutiny have been made by other state courts, which sometimes phrase the standard in novel ways. ${ }^{156}$

\footnotetext{
151. See Blankenship v. Bartlett, 681 S.E.2d 759, $764-65$ (N.C. 2009).

152. See King, 704 S.E.2d at 265.

153. Id.

154. See id.

155. Compare United States v. Virginia, 518 U.S. 515, 533 (1996) (noting, in a heightened application of intermediate scrutiny to gender discrimination, that "[t]he burden of justification is demanding and it rests entirely on the State”), with Clark v. Jeter, 486 U.S. 456, 461-65 (1988) (applying intermediate scrutiny but not indicating the burden is on the state to justify the statute).

156. See, e.g., State v. Stummer, 194 P.3d 1043, 1050 (Ariz. 2008) ("The appropriate test for measuring the constitutionality of content-based secondary effects regulations must vindicate the constitutional right to free speech, yet accommodate the government's interest in protecting the public health, safety, and welfare. The test has two phases. First, to qualify for intermediate scrutiny, the State must demonstrate that a content-based regulation is directed at ameliorating secondary effects, not at suppressing protected speech. Second, to survive intermediate scrutiny, the State must show that, in addressing the secondary effects, the regulation does not sweep too broadly.”); Davis v. Union Pac. R.R., 937 P.2d 27, 31-32 (Mont. 1997) (“Middle-tier scrutiny requires the state to demonstrate that its classification is reasonable and that its interest in the classification is greater than that of the individual's interest in the right infringed."). The rational basis test can also be reworked in state constitutional adjudications. See, e.g., id. at 32 ("When the
} 
An additional benefit of intermediate scrutiny is that it provides some scrutiny to challenged state actions. This is in contrast to rational basis review, which "has been characterized as 'virtually none in fact' because nearly every law subject to it survives judicial scrutiny." 157 Because it requires the courts to engage in actual inquiry, intermediate scrutiny ensures greater accountability for the actions of the legislative and executive branches. ${ }^{158}$

Similarly, by requiring only some scrutiny, intermediate review provides more respect for the coordinate branches than strict scrutiny. ${ }^{159}$ Adopting strict scrutiny to resolve one case can lead to unforeseen and potentially drastic results in the future. As Judge Sutton hypothesizes in his article analyzing the Rodriguez decision:

Had Rodriguez applied strict scrutiny to educational spending, taxing and policy decisions, as the plaintiffs requested, the decision almost certainly would have spawned a host of unintended consequences. The most obvious risk is that strict scrutiny would have presented too blunt an instrument to manage the calibrated policy choices that States and school districts must make in running a public school system. If education were a fundamental right entitled to skeptical review, imagine the next generation of constitutional challenges: Strict scrutiny over curriculum choices? Class size? Class schedules? Advanced Placement classes? Membership on a sports team? The possibilities are limitless. ${ }^{160}$

Intermediate scrutiny avoids such bluntness.

While the flexibility of intermediate scrutiny makes it valuable to the courts, it is also a potential drawback. Intermediate scrutiny is far from a bright-line standard, and variable articulations make the standard potentially difficult to apply. ${ }^{161}$ At times it seems like the most that can

right under examination is not determined to be fundamental and does not warrant middle-tier scrutiny, it is reviewed under a rational basis test. This test requires the government to show that the objective of the statute was legitimate and bears a rational relationship to the classification used by the Legislature.” (emphasis added)).

157. Adam Winkler, Scrutinizing the Second Amendment, 105 Mich. L. REv. 683, 718 (2007) (quoting Gerald Gunther, In Search of Evolving Doctrine on a Changing Court: A Model for a Newer Equal Protection, 86 HARV. L. REV. 1, 8 (1972)).

158. See Usman, supra note 61, at 1522 (“A rational basis review is not adequate to address challenges arising under positive rights provisions, for such an approach ignores the question of whether the legislature has satisfied the constitutionally mandated objective, or is at least making efforts that can be expected to achieve its constitutional duty.”).

159. See id. at 1510 ("[S]trict scrutiny imposes an arduous burden on the political branches ....”).

160. Sutton, supra note 123, at 1980.

161. See supra note 156 and accompanying text. 
be definitively said is that intermediate scrutiny is simply "in between" rational basis review and strict scrutiny. ${ }^{162}$ Compounding the fuzziness of the standard is the variability of judicial review within all three tiers of scrutiny. ${ }^{163}$ In sum, intermediate scrutiny may not be an appropriate solution when a bright line or clear legal rule is the aim.

In the context of separation of powers, intermediate scrutiny poses the additional concern that the judiciary may potentially intrude upon the executive and legislative roles. ${ }^{164}$ Although it is undoubtedly the role of the courts "to say what the law is," 165 courts must necessarily avoid judicial legislating. More rigorous forms of intermediate scrutinywhen not justified by clear constitutional violations-may violate the principle of separation of powers. Concomitantly, in requiring the government to articulate an important or significant reason for government action, application of intermediate scrutiny allows courts to operate as an effective bulwark against the exercise of putatively unconstitutional legislative and executive action. ${ }^{166}$

\section{CONCLUSION}

Attorneys — and the clients they represent—ultimately determine the number and type of state constitutional cases heard by state supreme courts. The growing reliance on state constitutional provisions leads to more interpretations of state constitutions that provide more precedent for future challenges, as can be seen in Stephenson and Blankenship. ${ }^{167}$ Each state constitutional challenge requires the appellate courts to interpret the state constitution and precedent in new factual contexts, as can be seen by the resolution of the Leandro standard in King. ${ }^{168}$ In many of these state constitutional adjudications, intermediate scrutiny is a tool courts may use to resolve conflicts in the legal landscape. Like

\footnotetext{
162. See supra note 69 and accompanying text.

163. See supra note 68 and accompanying text.

164. See Usman, supra note 61, at 1523 ("A more rigorous review than federal rational basis analysis, however, raises well-founded concerns about removing issues and questions from the realm of self-government, and in doing so, eliminating citizen participation.”).

165. Marbury v. Madison, 5 U.S. (1 Cranch) 137, 177 (1803); see also THE FEDERALIST No. 78, at 394 (Alexander Hamilton) (Ian Shapiro ed., 2009) ("The interpretation of the laws is the proper and peculiar province of the courts. A constitution is, in fact, and must be regarded by the judges, as a fundamental law. It therefore belongs to them to ascertain its meaning, as well as the meaning of any particular act proceeding from the legislative body.”).

166. See THE FEDERALIST No. 51 (James Madison).

167. See supra Part III.B.

168. See supra Part III.C.
} 
any mechanism for legal analysis, intermediate scrutiny has its benefits and drawbacks. Only time will tell whether state supreme courts will turn to intermediate scrutiny more frequently as they discharge their duty to interpret state constitutions. 